Article

\title{
Separation of Oxidized Pyrrhotite from Fine Fraction Serpentine
}

\author{
Jian Zhou, Yiping Lu * and Guozhi Mao * \\ School of Minerals Processing and Bioengineering, Central South University, Changsha 410083, China; \\ zhoujian@csu.edu.cn \\ * Correspondence: yplu_csu@163.com (Y.L.); maoguozhi@csu.edu.cn (G.M.)
}

Received: 29 August 2018; Accepted: 19 October 2018; Published: 22 October 2018

\begin{abstract}
The valuable minerals in copper-nickel sulfide ore can easily be oxidized, leading to the reduction of their flotation recovery and a difficulty in separating them from gangue. In order to solve the problem, the reaction mechanism of the octanohydroxamic acid (OHA) on oxidized pyrrhotite was revealed through micro-flotation, adsorption tests, zeta potential measurements, and X-ray photoelectron spectroscopy (XPS) analysis. The results show that this is a feasible way to find a suitable collector that can directly react to oxidation products on the surface of pyrrhotite. OHA can efficiently reclaim oxidized pyrrhotite and achieve the selective separation of a pyrrhotite-serpentine mixture in a weak alkaline environment. The adsorption tests, zeta potential measurements, and XPS analyses show that OHA can interact with an oxidized pyrrhotite surface, and the interaction between OHA and serpentine is very weak. The XPS analyses indicate that the OHA collector can chelate with $\mathrm{Fe}(\mathrm{OH})_{3}$ on the surface of oxidized pyrrhotite and form an "O, O" five-ring chelate. At the same time, the OHA collector may compete with the hydroxyl groups of hydrophilic substances on the mineral surface to produce hydrophobic products and reduce the hydrophilic substances on the mineral surface.
\end{abstract}

Keywords: octanohydroxamic acid (OHA); pyrrhotite; oxidation; chelate

\section{Introduction}

Froth flotation, a widely-used treatment of base metal sulfides, relies on the differences in surface properties between sulfide minerals and non-sulfide minerals. However, these differences become increasingly marginal as the sulfide mineral surface becomes oxidized [1-4]. Oxidation of the sulfide mineral surface is an important phenomenon, which represents one of the central issues in the flotation practice of complex sulfide ores, as the floatability of sulfide particles is controlled by the level of surface oxidation [5-11]. A moderate surface oxidation of sulfide minerals is known to be beneficial for the adsorption of collectors and the formation of a hydrophobic surface, i.e., slight surface oxidation can increase the floatability of sulfide minerals [6]. However, once sulfide minerals are heavily oxidized, the floatability of sulfide minerals decreases sharply, which may be mainly due to the formation of metal hydroxide species on the surface of sulfide minerals [12,13]. As a result, a collector cannot effectively collect the valuable sulfide minerals unless the dosage is significantly increased [1].

Jinchuan Nickel Mine is the largest nickel producer in China [14]. The valuable minerals in the ore of this mine are mainly pentlandite, chalcopyrite, violarite, and pyrrhotite. Pyrrhotite is a complex iron sulfide mineral that can be found in many base metal sulfide ores. It is an iron-deficient mineral with the formula $\mathrm{Fe}_{(1-\mathrm{x})} \mathrm{S}(0<\mathrm{x} \leq 0.125)$, which results in numerous compositions with different $\mathrm{Fe} / \mathrm{S}$ ratios, commonly referred to as pyrrhotite superstructures [15]. Pyrrhotite is one of the most abundant iron sulfide minerals. It is found in nature and is commonly associated with pentlandite, quartz, ankerite $\left(\mathrm{CaFe}\left(\mathrm{CO}_{3}\right)_{2}\right)$, pyrite, chalcopyrite, and other sulfide minerals [16]. In many flotation 
plants, pyrrhotite is often discharged to the flotation tailings as a waste product. However, a strong interest in pyrrhotite recovery arises when pyrrhotite contains $\mathrm{Ni}$, platinum group metals (PGM), and other precious metals [16,17]. In addition, pyrrhotite is also one of the most reactive sulfide minerals. It is well established that the flotation recovery of pyrrhotite is highly influenced by the level of oxidation; the oxidation of the pyrrhotite may occur during all stages of the process, from milling to flotation $[18,19]$. Moreover, the oxidation products, such as iron hydroxides, oxyhydroxides, and oxides, form a coating on the mineral surfaces of pyrrhotite [2], which can interfere with the flotation. Serpentine is the dominant gangue in sulfide mineral flotation and is often associated with many metal sulfide ore deposits $[14,20]$. The gangue can also interfere with flotation by forming a coating on the sulfide mineral surface, which has two consequences: The dilution of the concentrate when the partially coated sulfide remains floatable, and the lowering of sulfide recovery when the extensively coated sulfide becomes hydrophilic [14,21].

Xanthates are some of the most commonly used collectors for the flotation of sulfide minerals and are capable of recovering pyrrhotite well when the surface of the pyrrhotite is not oxidized in the weak alkaline environment. As the degree of oxidation of pyrrhotite increases, the ability of xanthate to collect pyrrhotite decreases sharply $[5,17,22]$. The time during which the samples were exposed to air, counted from the end of milling, is denoted as the exposure time (ET), and the degree of oxidation is measured by the exposure time (ET) of minerals. There is a significant decrease in the recovery of pyrrhotite using sodium butyl xanthate (SBX) as a collector when ET $=24 \mathrm{~h}[19,23]$. Hydroxamic acids, $\mathrm{R}-\mathrm{CO}-\mathrm{NHOH}$ ( $\mathrm{R}$, alkyl/aryl group), are much weaker acids than the corresponding carboxylic acids, in the identical carbon chain, but possess stronger abilities in selectively chelating metal ions [24]. Hydroxamic acids can chelate with metal cations (e.g., $\mathrm{Cu}^{2+}, \mathrm{Fe}^{3+}, \mathrm{Al}^{3+}$ ) to form hydrophobic metal chelates $[24,25]$, and the chelation reaction for hydroximic acids to metal cation can form an " $\mathrm{O}, \mathrm{N}$ " four-ring chelate and/or an " $\mathrm{O}, \mathrm{O}$ " five-ring chelate (the chelate products are shown in Figure 1). Since the tension of the four-ring chelate is relatively high, and the stability is poor, the chelate product is mainly a five-ring chelate.

In this paper, the Octanohydroxamic acid (OHA) was introduced as a flotation collector to solve the problem that oxidized pyrrhotite and serpentine are difficult to separate. Micro-flotation tests were performed to reveal the selective flotation of pyrrhotite by OHA. In addition, the underlying mechanism was investigated through adsorption tests, zeta potential measurements, and XPS analysis.
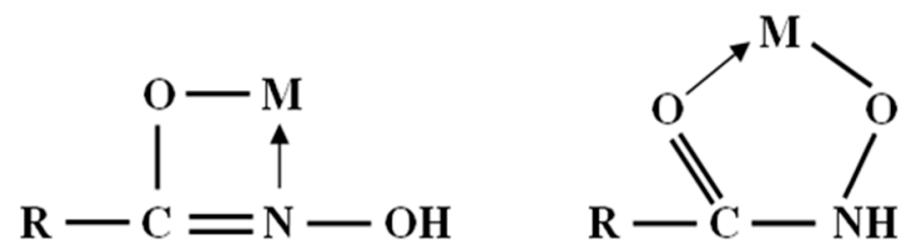

Figure 1. Chelate products of hydroximic acid with metal cations.

\section{Materials and Methods}

\subsection{Materials}

\subsubsection{Minerals}

The pyrrhotite specimen in this work was obtained from Tongling in the Anhui Province of China. It was handpicked to ensure a high purity specimen for this test work. The specimen was then milled in a ceramic ball mill, followed by dry sieving to extract the $-74 \mu \mathrm{m}$ size fraction used in this study. The XRD quantitative analysis showed that the purity of pyrrhotite was above $95 \%$. The results of the elemental analysis of a pyrrhotite single mineral (mass fraction) are presented in Table 1. The serpentine was obtained from Donghai, Jiangsu Province, China, and was chosen as the gangue mineral. The particle size analysis and elemental analysis results of a serpentine single mineral (mass fraction) of serpentine are presented in Tables 2 and 3, respectively. The artificially mixed ore was prepared by mixing pyrrhotite and serpentine 
samples at a weight ratio of 1:1. For Zeta potential measurements, the finer fraction $(-5 \mu \mathrm{m})$ was used. In order to oxidize the pyrrhotite samples used in the experiment, the samples were exposed to air for $24 \mathrm{~h}$ (denoted as ET $=24 \mathrm{~h}$ ), counted from the end of milling.

Table 1. Chemical compositions of the pyrrhotite single mineral (mass fraction/\%).

\begin{tabular}{ccccccc}
\hline TFe & $\mathbf{S}$ & $\mathbf{P}$ & $\mathrm{SiO}_{2}$ & $\mathbf{M g O}$ & $\mathbf{C a O}$ & $\mathbf{C u}$ \\
\hline 58.68 & 39.34 & 0.001 & 0.41 & 0.05 & 0.21 & 0.06 \\
\hline
\end{tabular}

Table 2. The particle size analysis of serpentine $(\mu \mathrm{m})$.

\begin{tabular}{ccccc}
\hline Sample & $\mathbf{d}_{\mathbf{1 0}}$ & $\mathbf{d}_{\mathbf{5 0}}$ & $\mathbf{d}_{\mathbf{9 0}}$ & Average Size \\
\hline Serpentine & 1.71 & 15.10 & 48.73 & 20.70 \\
\hline
\end{tabular}

Table 3. Chemical compositions of the serpentine single mineral (mass fraction/\%).

\begin{tabular}{cccccccc}
\hline $\mathbf{M g O}$ & $\mathrm{SiO}_{2}$ & $\mathrm{Fe}_{2} \mathbf{O}_{\mathbf{3}}$ & $\mathbf{N i O}$ & $\mathrm{Al}_{\mathbf{2}} \mathbf{O}_{\mathbf{3}}$ & $\mathbf{C a O}$ & $\mathbf{K}_{\mathbf{2}} \mathbf{O}$ & Others \\
\hline 32.92 & 37.10 & 7.39 & 0.37 & 0.80 & 0.21 & 0.06 & 21.15 \\
\hline
\end{tabular}

\subsubsection{Reagents}

Octanohydroxamic acid (OHA) was bought from a commercial company, and its purity was above $98 \%$. Sodium butyl xanthate (SBX) with 93\% purity was used as the collector and was obtained from Zhuzhou Flotation Reagent Company. Methyl Isobutyl Carbinol (MIBC) acts as the frother and was an industrial product. Sodium hexametaphosphate (SHMP, AR) was used as the dispersant in this study, and hydrochloric acid $(\mathrm{HCl})$ and sodium hydroxide $(\mathrm{NaOH})$ of analytical grade were both used as $\mathrm{pH}$ regulators and were added to the micro-flotation tests.

\subsection{Experimental}

\subsubsection{Micro-Flotation Tests}

Micro-flotation tests were conducted in a micro-flotation cell with a volume of $40 \mathrm{~mL}$, and the contents of the cell were stirred at $1650 \mathrm{rpm}$ by a four-bladed impeller. A PHS-3C acidometer, built by Shanghai Leici Company (Shanghai, China), was used to measure the $\mathrm{pH}$ value. The micro-flotation tests involved the following procedures: (1) Wetting the single minerals $(2 \mathrm{~g})$ or mineral mixture $(1 \mathrm{~g}$ pyrrhotite plus $1 \mathrm{~g}$ serpentine) with $40 \mathrm{~mL}$ de-ionized water for $1 \mathrm{~min}$; (2) adding the pH regulator for the required $\mathrm{pH}$ and agitating for $2 \mathrm{~min}$; (3) if necessary, adding the depressant and agitating for $3 \mathrm{~min}$; (4) adding the collector and agitating for $3 \mathrm{~min}$; (5) after adding the frother, collecting the floating materials for $3 \mathrm{~min}$; and (6) filtering the collected materials, and drying and weighing them for recovery calculation and chemical analyses. Micro-flotation tests were only used for assessing the flotation of single pure minerals and the separation of the artificial mixture of pyrrhotite-serpentine. For single mineral flotation, the flotation recovery was calculated based on the dry weight of the products obtained. For mixed minerals (the ratio of pyrrhotite and serpentine was 1:1) flotation, the flotation recovery was calculated based on $\mathrm{S}$ and $\mathrm{MgO}$ grades between the concentrates and tailings. Each flotation experiment was repeated at least three times, and the average flotation recovery value was calculated. The error of the recovery was found to be within $3.0 \%$.

In the weakly alkaline $\mathrm{pH}$ range, where sulfide mineral flotation was commonly used, the serpentine surface is positively charged, and the sulfide mineral surface is negatively charged. Strong electrostatic attraction exists between the two minerals, which resulted in heterogeneous agglomeration. Heterogeneous agglomeration leads to the formation of a serpentine slime coating on the sulfide mineral surfaces and depresses the flotation of sulfide minerals [26]. 
In the field of mineral processing, polyphosphates have been used as depressants, which disperse agents for slimes, stabilizers for mineral suspensions, which precipitate agents for some metal ions, and as a water-softening agent. SHMP (Sodium hexametaphosphate) is one of the most important polyphosphates with these functions [27]. SHMP usually has a mean molecular weight of 12,000 to 18,000 and up to $200 \mathrm{PO}_{3}$ units in the chain [28]. In the flotation process, it was widely used to disperse slime that might attach to valuable mineral surfaces by increasing the repulsive energy between particles. Thus, here, SHMP was chosen as the dispersant for the separation of pyrrhotite from the pyrrhotite-serpentine mixture in combination with the OHA as the collector.

\subsubsection{Adsorption Studies}

In this study, the collector adsorption amount on the mineral particle surface was calculated by the residual concentration method. For each adsorption test, $2 \mathrm{~g}$ of the mineral was added into an $80 \mathrm{~mL}$ conical flask with a $40 \mathrm{~mL}$ collector solution, which was prepared at the desired concentration. The total volume was $40 \mathrm{~mL}$, and the $\mathrm{pH}$ value was adjusted to the desired $\mathrm{pH}$. Then, the suspension in the sealed conical flask was performed with the SHZ-82A thermostatic oscillator at $298( \pm 1) \mathrm{K}$ for $30 \mathrm{~min}$. Centrifugation was used to separate the solid and liquid, with a set speed of $9000 \mathrm{rpm}$ for $20 \mathrm{~min}$, and the supernatant was used for the following tests. The concentration of OHA in the

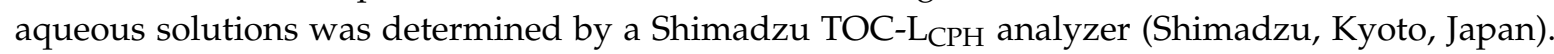
The equilibrium concentration of SBX in the solution was measured by UV spectrophotometry, and the value was calculated from the standard curve of SBX, which was obtained by different concentrations of SBX (absorbance at $301 \mathrm{~nm}$ ). The adsorption of collectors was calculated by the difference between the initial and the residual concentrations of the solutions. The specific surface area of the two minerals was measured with an automatic specific surface analyzer (Monosorb, Quantachrome Corp., Boynton Beach, FL, USA). The BET surface areas of pyrrhotite and serpentine were measured at 1.26 and $1.34 \mathrm{~m}^{2} / \mathrm{g}$, respectively.

\subsubsection{Zeta Potential Measurements}

The zeta potentials of pyrrhotite and serpentine samples were measured using the Coulter Delsa440sx Zeta Potential \& Size Analyzer (Beckman Coulter, Inc., Brea, CA, USA). Next, 50 mg of samples $(-5 \mu \mathrm{m})$ was added to $40 \mathrm{~mL} 0.01 \mathrm{~mol} / \mathrm{L} \mathrm{KCl}$ solutions, in the absence or presence of $5 \times 10^{-5} \mathrm{~mol} / \mathrm{L} \mathrm{OHA}$, after the pulp was stirred with a magnetic stirrer for $5 \mathrm{~min}$. Then, the $\mathrm{pH}$ values were adjusted with hydrochloric or sodium hydroxide solutions and measured, and the agitated suspension was sampled to record the zeta potentials. The average value of at least three independent measurements of zeta potential was reported as the zeta potential of a point.

\subsubsection{XPS Analysis}

X-ray photoelectron spectroscopy (XPS) was used to detect the changes of the mineral surface, in the absence or presence of $5 \times 10^{-4} \mathrm{~mol} / \mathrm{L} \mathrm{OHA}$. The measurements were performed using an ESCALAB 250Xi X-ray photoelectron spectrometer, manufactured by Thermo Fisher Scientific Inc, Waltham, MA, USA. For the measurements, $2 \mathrm{~g}$ of the mineral sample was agitated in the flotation cell at $\mathrm{pH} \mathrm{8,} \mathrm{according} \mathrm{to} \mathrm{the} \mathrm{corresponding} \mathrm{reagent} \mathrm{condition,} \mathrm{for} 30 \mathrm{~min}$. Centrifugation was used to separate the solid and liquid, with a set speed of $9000 \mathrm{rpm}$, for $10 \mathrm{~min}$. Additionally, the solid mineral, after centrifugation, was washed with ultrapure water twice, then dried in a vacuum drying oven, at a temperature of $298 \mathrm{~K}$, for XPS analysis.

\section{Results and Discussion}

\subsection{Flotation of Pyrrhotite and Serpentine with Two Collectors}

The effect of pulp $\mathrm{pH}$ values on the flotation recovery of pyrrhotite $(\mathrm{ET}=24 \mathrm{~h})$, using $\mathrm{OHA}(\mathrm{OHA}$ concentration: $4 \times 10^{-5} \mathrm{~mol} / \mathrm{L}$ ) or SBX (SBX concentration: $1 \times 10^{-3} \mathrm{~mol} / \mathrm{L}$ ) as collectors, was studied, 
and the results are shown in Figure 2. It can be seen, from Figure 2, that the favorable pH values for the recovery of pyrrhotite (using OHA as a collector) were 4-10, and pulp pH values of less than 4 or above 10 would decrease the flotation recovery of pyrrhotite. At $\mathrm{pH} 8$, the pyrrhotite has a very good floatability, with a flotation recovery of above $95 \%$. However, the flotation recovery of pyrrhotite $(\mathrm{ET}=24 \mathrm{~h})$ decreased sharply as the $\mathrm{pH}$ increased, using SBX as a collector. The maximum recovery of pyrrhotite was about $85 \%$ at $\mathrm{pH} 2$.

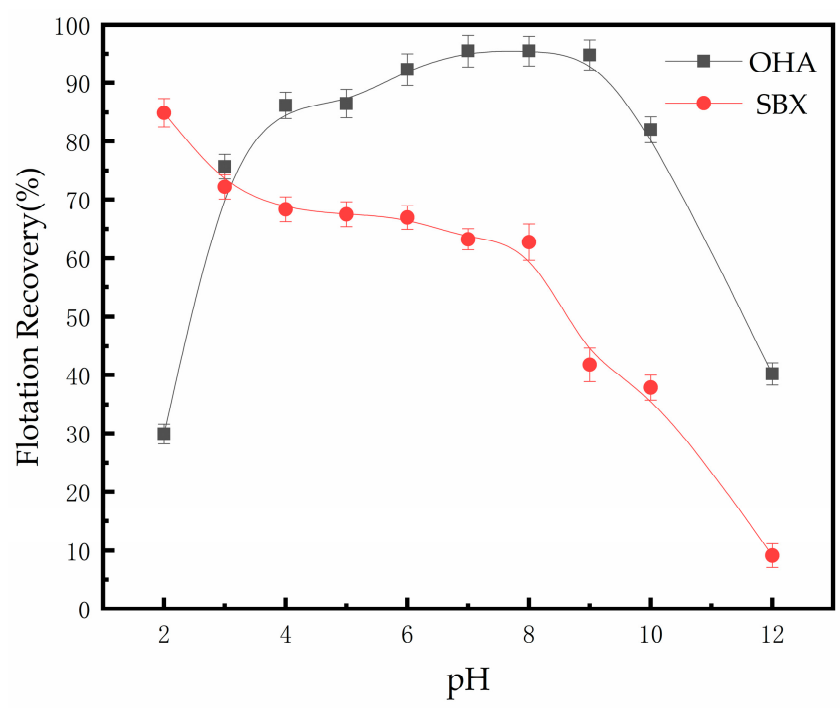

Figure 2. Effect of pulp $\mathrm{pH}$ values on the flotation of pyrrhotite $(\mathrm{ET}=24 \mathrm{~h})$.

The results of the micro-flotation of the single pyrrhotite $(\mathrm{ET}=24 \mathrm{~h})$ and serpentine minerals, as a function of the OHA dosage at $\mathrm{pH}$ 8.0, are summarized in Figure 3. It can be seen, from Figure 3a, that the flotation recovery of pyrrhotite increased rapidly with the increase in the OHA concentration. The recovery of pyrrhotite, at $4 \times 10^{-5} \mathrm{~mol} / \mathrm{L} \mathrm{OHA}$, was almost $90 \%$. At the same time, in the same OHA concentration range, the recovery of fine serpentine remained low as the concentration was increased, and the maximum recovery of serpentine was only about $15 \%$. However, as can be observed from Figure $3 b$, the recovery of pyrrhotite slowly increased with the increasing collector concentration and reached $68.74 \%$ at a $1 \times 10^{-3}$ $\mathrm{mol} / \mathrm{L} \mathrm{SBX}$ dosage. It can be inferred from the results of the micro-flotation tests that the OHA has an excellent ability to collect the surface-oxidized pyrrhotite under a weakly alkaline condition and has a poor ability to capture the serpentine. Therefore, the OHA has good selectivity.

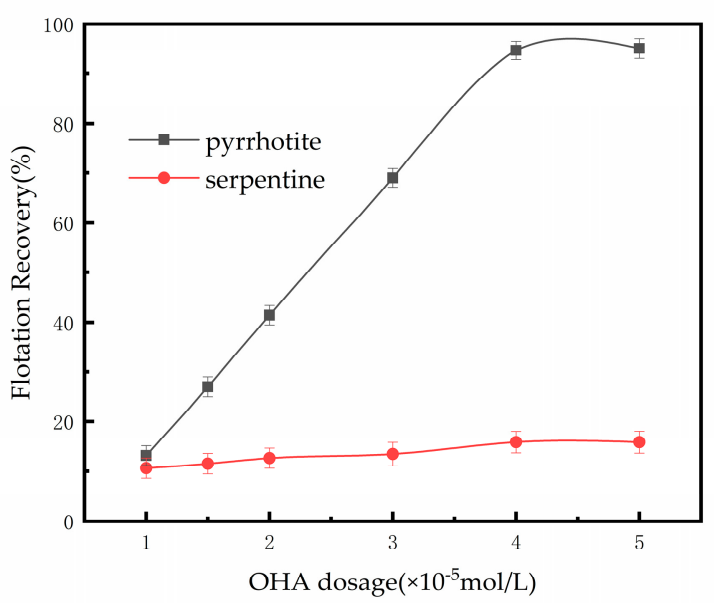

(a)

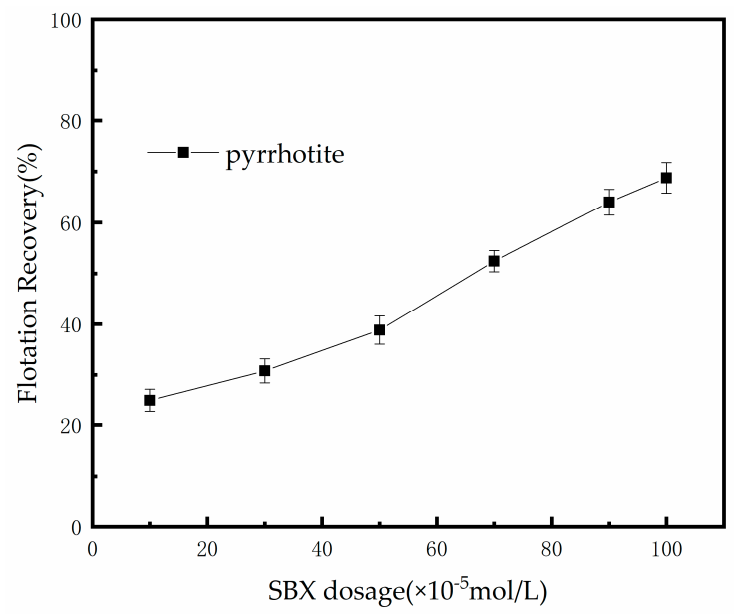

(b)

Figure 3. Effect of the collector dosage ((a): OHA, (b): SBX) on the flotation of pyrrhotite $(\mathrm{ET}=24 \mathrm{~h})$. 


\subsection{Separation of Pyrrhotite from Pyrrhotite-Serpentine Mixture}

The single mineral flotation tests indicate a large separation window at $\mathrm{pH}$ 8.0. Hence, the mixed-mineral flotation tests were carried out to examine the possibility of using OHA as a collector in the flotation separation of the pyrrhotite-serpentine mixture.

The results of the chemical analysis and the recovery of the flotation of pyrrhotite-serpentine mixture concentrates (OHA concentration: $4 \times 10^{-5} \mathrm{~mol} / \mathrm{L}$ ) at $\mathrm{pH} 8.0$, are shown in Table 4 . It can be seen from Table 4 that OHA has good selectivity when separating oxidized pyrrhotite and fine-grained serpentine by flotation; the recoveries of pyrrhotite $(\mathrm{ET}=24 \mathrm{~h})$ and serpentine at an $8 \mathrm{mg} / \mathrm{L}$ dosage of SHMP were $87.32 \%$ and $13.03 \%$, respectively.

Table 4. Results of the chemical analysis and the recovery of artificially mixed minerals.

\begin{tabular}{ccccccc}
\hline Number & SHMP (mg/L) & Yield (\%) & S grade (\%) & MgO Grade (\%) & Recovery of Pyrrhotite (\%) & Recovery of Serpentine (\%) \\
\hline 1 & 0 & 48.51 & 31.27 & 5.99 & 77.12 & 16.64 \\
2 & 5 & 50.00 & 33.49 & 5.34 & 85.13 & 15.29 \\
3 & 8 & 49.47 & 34.72 & 4.60 & 87.32 & 13.03 \\
4 & 10 & 48.43 & 34.95 & 4.10 & 79.73 & 11.37 \\
5 & 15 & 44.44 & 35.29 & 4.01 & 74.95 & 8.21 \\
6 & 20 & 41.02 & 35.91 & 3.66 & & 8.60 \\
\hline
\end{tabular}

As the dosage of SHMP increased from $0 \mathrm{mg} / \mathrm{L}$ to $20 \mathrm{mg} / \mathrm{L}$, the yield and recovery of pyrrhotite $(\mathrm{ET}=24 \mathrm{~h})$ increased at first and then decreased, and the maximum value of the yield and recovery of pyrrhotite $(\mathrm{ET}=24 \mathrm{~h}$ ) reached $50 \%$ and $87.32 \%$, respectively. Meanwhile, the recovery of serpentine gradually decreased from $16.64 \%$ to $8.60 \%$. Therefore, with an appropriate dosage of SHMP, the OHA can collect oxidized pyrrhotite $(\mathrm{ET}=24 \mathrm{~h})$ from a pyrrhotite-serpentine mixture very well, but its ability to collect serpentine is weak.

\subsection{Adsorption Studies}

The adsorbed amount of OHA (OHA concentration: $1 \times 10^{-4} \mathrm{~mol} / \mathrm{L}$ ) or SBX (SBX concentration: $\left.1 \times 10^{-3} \mathrm{~mol} / \mathrm{L}\right)$ on the surfaces of pyrrhotite $(\mathrm{ET}=24 \mathrm{~h})$, as a function of $\mathrm{pH}$ values, is shown in Figure 4. As can be seen from Figure 4, the optimum adsorption range of $\mathrm{OHA}$ is $\mathrm{pH}=6-10$, and $\mathrm{pH}$ values of less than 6 or above 10 would decrease the adsorption amount of OHA on the surface of pyrrhotite. The adsorbed amount of SBX on the surface of pyrrhotite $(E T=24 \mathrm{~h})$ decreased sharply as the $\mathrm{pH}$ values increased.

The adsorbed amount of OHA on the surfaces of both pyrrhotite $(\mathrm{ET}=24 \mathrm{~h})$ and serpentine, as a function of the collector dosage at $\mathrm{pH}$ 8.0, is shown in Figure 5. The result of Figure 5 illustrated that, at $\mathrm{pH}$ 8.0, the adsorption amount of OHA on pyrrhotite $(\mathrm{ET}=24 \mathrm{~h})$ and serpentine both increased with the increase of the OHA concentration, and pyrrhotite $(\mathrm{ET}=24 \mathrm{~h})$ showed a high adsorption capacity, while the amount of adsorption for serpentine was consistently low.

By comparing the flotation tests, the effect of $\mathrm{pH}$ on the adsorption amount of the two collectors is consistent with the flotation results. The adsorbed amount of the two collectors on the surface of pyrrhotite $(\mathrm{ET}=24 \mathrm{~h})$ is quite similar within the collector concentration range of $5 \times 10^{-5} \mathrm{~mol} / \mathrm{L}-5$ $\times 10^{-4} \mathrm{~mol} / \mathrm{L}$. However, the collector ability of OHA is much stronger than that of SBX. In addition, the adsorbed amount of OHA on the surfaces of both pyrrhotite $(E T=24 \mathrm{~h})$ and serpentine became more dissimilar as the amount of OHA increased in the collector concentration range experiments at $\mathrm{pH}$ 8.0. The adsorption of $\mathrm{OHA}$ on the surfaces of both pyrrhotite $(\mathrm{ET}=24 \mathrm{~h})$ and serpentine has good selectivity. 


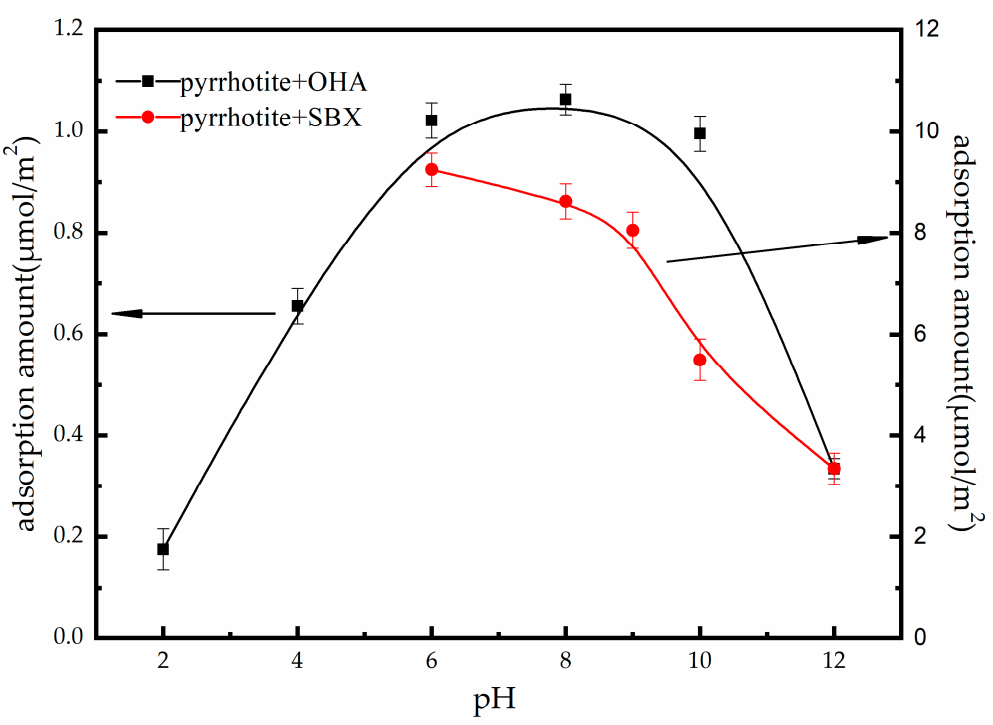

Figure 4. The adsorbed amount of the two collectors on the surfaces of pyrrhotite $(\mathrm{ET}=24 \mathrm{~h})$, as a function of $\mathrm{pH}$ values (octanohydroxamic acid (OHA) concentration: $1 \times 10^{-4} \mathrm{~mol} / \mathrm{L}$, SBX concentration: $\left.1 \times 10^{-3} \mathrm{~mol} / \mathrm{L}\right)$.

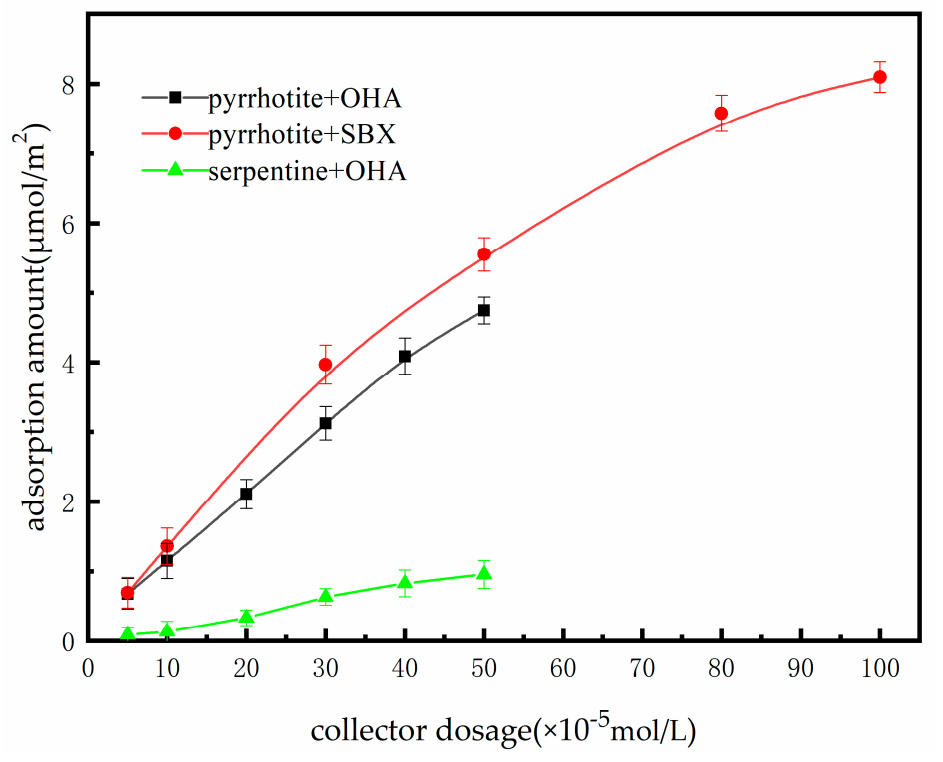

Figure 5. The adsorbed amount of the two collectors on the surfaces of pyrrhotite $(\mathrm{ET}=24 \mathrm{~h})$, as a function of the collector dosage $(\mathrm{pH}=8.0)$.

\subsection{Zeta Potential Measurements}

In order to investigate the adsorption mechanism of OHA on the surfaces of the two minerals, zeta potential measurements were carried out. The zeta potentials of pyrrhotite $(\mathrm{ET}=24 \mathrm{~h})$ and serpentine, as a function of the suspension of $\mathrm{pH}$ values, in the absence and presence of $\mathrm{OHA}$, are listed in Figure 6. As can be seen in Figure 6a, the surface zeta potential of pyrrhotite $(E T=24 \mathrm{~h}$ ), in the absence of OHA, gradually decreased and changed from positive to negative at $\mathrm{pH} 6.5$, as the $\mathrm{pH}$ value increased, indicating that the point of zero charge (PZC) of pyrrhotite is $\mathrm{pH}$ 6.5. When OHA was added, the zeta potentials of pyrrhotite (ET $=24 \mathrm{~h}$ ) shifted, to some extent, to more negative values in the whole examined $\mathrm{pH}$ range. It was understandable that the zeta potential became more negative because the anionic collector, OHA, adsorbed on the surface of pyrrhotite.

It can be seen from Figure $6 \mathrm{~b}$ that the surface zeta potential of serpentine was insensitive to the addition of OHA and remained almost the same as that without OHA. The surface zeta potential of 
serpentine gradually decreased and changed from positive to negative at $\mathrm{pH} 11.5$, before and after the addition of $\mathrm{OHA}$, as the $\mathrm{pH}$ value increased, indicating that the $\mathrm{PZC}$ of serpentine is $\mathrm{pH} 11.5$. After the action of the OHA collector, the zeta potential of serpentine changed very little. It can be concluded that the anionic collector, OHA, had a slight effect on the zeta potential of serpentine.

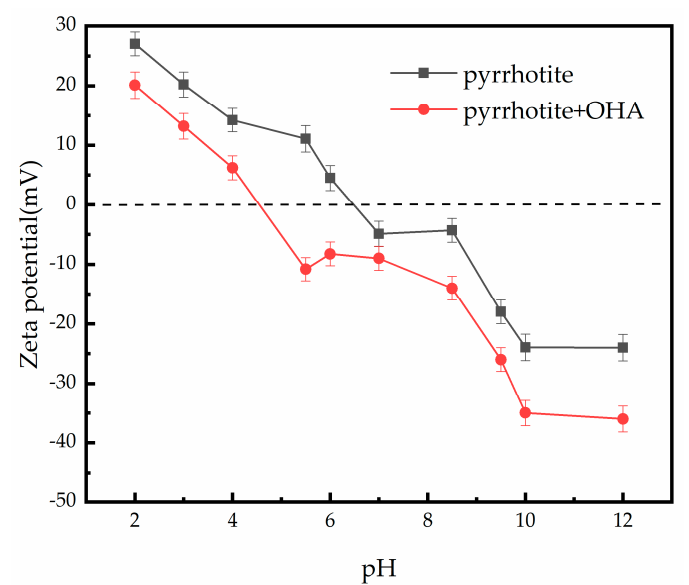

(a)

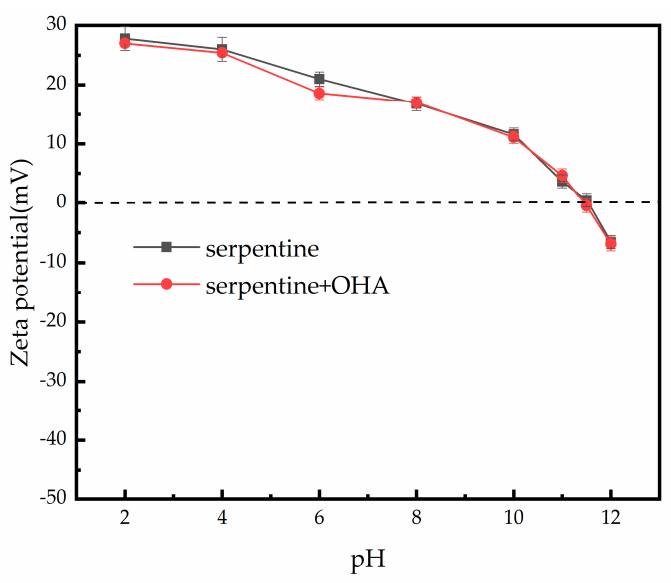

(b)

Figure 6. Effect of OHA on the zeta potentials of pyrrhotite (a) and serpentine (b).

By comparing the changes of zeta potential, before and after the interaction of pyrrhotite $(\mathrm{ET}=24 \mathrm{~h})$ and serpentine with OHA, it can be concluded that the adsorption effect of the anionic collector, OHA, on the surface of pyrrhotite $(\mathrm{ET}=24 \mathrm{~h}$ ) is good and on the surface of serpentine is weak. The results obtained from the zeta potential measurements are in agreement with the previous adsorption results. From the perspective of the molecular structure, in which the OHA is considered an anionic collector, it is understandable that the zeta potential became more negative, due to ionization of the anionic OHA, once the anionic collector OHA adsorbed on the surface of pyrrhotite. However, that the anionic collector OHA adsorbed on the negative surface of pyrrhotite cannot be fully explained by an electrostatic attraction, and specific adsorption or/and some chemically based compounds may be involved [27].

\subsection{XPS Analysis}

X-ray photoelectron spectroscopy (XPS) analysis was utilized to investigate the adsorption mechanism of OHA on pyrrhotite $(\mathrm{ET}=24 \mathrm{~h})$ and serpentine. The shift energies of valence electrons on the surfaces of pyrrhotite $(\mathrm{ET}=24 \mathrm{~h})$ and serpentine, before and after treatment with OHA (OHA concentration: $5 \times 10^{-4} \mathrm{~mol} / \mathrm{L}, \mathrm{pH}=8.0$ ), are shown in Table 5, and the O1s and N1s spectra of pyrrhotite $(\mathrm{ET}=24 \mathrm{~h})$ and pyrrhotite $(\mathrm{ET}=24 \mathrm{~h})$ treated with OHA $(\mathrm{OHA}$ concentration: $5 \times 10^{-4} \mathrm{~mol} / \mathrm{L}, \mathrm{pH}=8.0$ ) are shown in Figures 7 and 8 , respectively.

Table 5. The shift energies of valence electrons on the surfaces of pyrrhotite $(E T=24 \mathrm{~h})$ and serpentine, before and after treatment with $\mathrm{OHA}$ (Binding Energy/ $\Delta \mathrm{E}: \mathrm{eV}$ ).

\begin{tabular}{ccccc}
\hline \multirow{2}{*}{ Electronic Orbital } & Pyrrhotite & Serpentine & Pyrrhotite + OHA & Serpentine + OHA \\
\cline { 2 - 5 } & Binding Energy & Binding Energy & Binding Energy $\Delta \mathrm{E}$ & Binding Energy $\Delta \mathrm{E}$ \\
\hline \multirow{2}{*}{$\mathrm{C} 1 \mathrm{~s}$} & 284.80 & 284.80 & $\begin{array}{c}284.80 \\
0\end{array}$ & $\begin{array}{c}284.80 \\
0\end{array}$ \\
\hline \multirow{2}{*}{$\mathrm{O} 1 \mathrm{~s}$} & 531.50 & 531.41 & $\begin{array}{c}531.35 \\
0.15\end{array}$ & $\begin{array}{c}531.41 \\
0\end{array}$ \\
\hline \multirow{2}{*}{$\mathrm{Fe} 2 \mathrm{p}$} & 710.68 & - & $\begin{array}{c}710.50 \\
0.18\end{array}$ & - \\
\hline \multirow{2}{*}{$\mathrm{Mg} 1 \mathrm{~s}$} & - & 1303.00 & - & $\begin{array}{c}3303.04 \\
0.04\end{array}$ \\
\hline
\end{tabular}


The binding energy of O1s and Fe2p of pyrrhotite $(\mathrm{ET}=24 \mathrm{~h})$ underwent a change of $0.15 \mathrm{eV}$ and $0.18 \mathrm{eV}$ after OHA treatment, respectively, which indicated that the chemical environment of Fe and $\mathrm{O}$ atoms experienced changes, and OHA was chemically adsorbed on the surface of pyrrhotite $(E T=24 \mathrm{~h})$ [25]. However, the binding energy of the O1s of serpentine had not changed in the presence of OHA. At the same time, the binding energy of the Mg1s of serpentine had only changed by $0.04 \mathrm{eV}$, which indicated that the chemical environment of $\mathrm{O}$ and $\mathrm{Mg}$ atoms did not change.

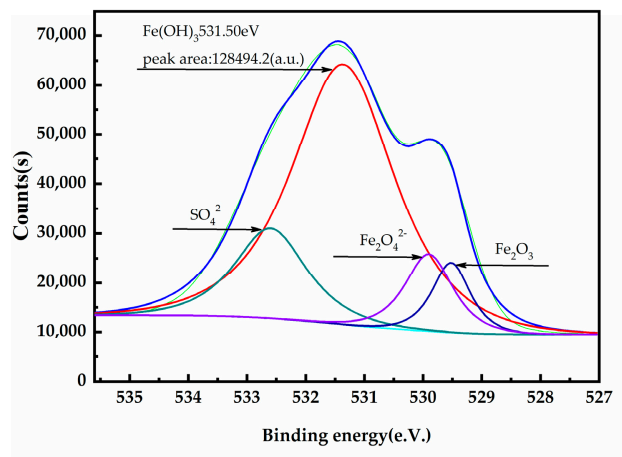

(a)

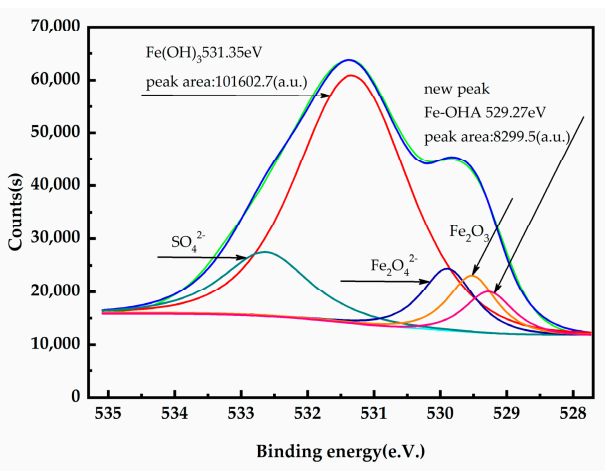

(b)

Figure 7. O1s narrow region scan of $(\mathbf{a})$ pyrrhotite $(\mathrm{ET}=24 \mathrm{~h})$ and $(\mathbf{b})$ pyrrhotite $(\mathrm{ET}=24 \mathrm{~h})$ treated with OHA (OHA concentration: $5 \times 10^{-4} \mathrm{~mol} / \mathrm{L}, \mathrm{pH}=8.0$ ).

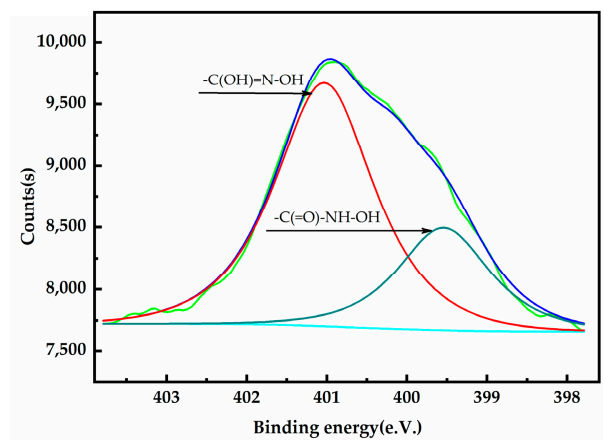

(a)

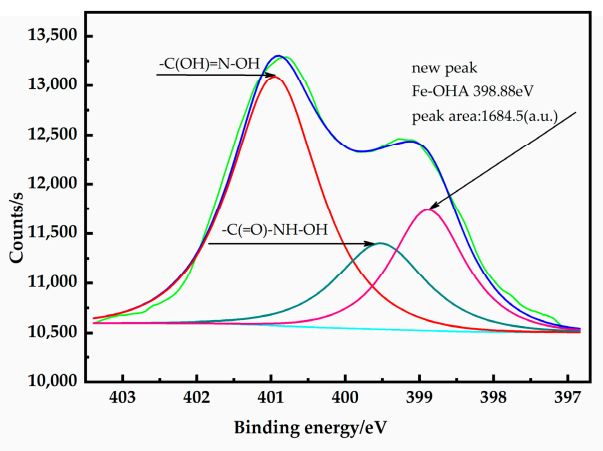

(b)

Figure 8. N1s narrow region scan of $(\mathbf{a}) \mathrm{OHA}$ and $(\mathbf{b})$ pyrrhotite $(\mathrm{ET}=24 \mathrm{~h})$ treated with $\mathrm{OHA}(\mathrm{OHA}$ concentration: $\left.5 \times 10^{-4} \mathrm{~mol} / \mathrm{L}, \mathrm{pH}=8.0\right)$.

With reference to the data from the United States National Institute of Standards and Technology (NIST) [29], the binding energy of $531.35 \mathrm{eV}$ corresponds to $\mathrm{Fe}(\mathrm{OH})_{3}$, which indicates that a hydrophilic substance on the surface of oxidized pyrrhotite $(\mathrm{ET}=24 \mathrm{~h})$ is mainly $\mathrm{Fe}(\mathrm{OH})_{3}$. As can be seen from Figure 7, a new peak ( $529.27 \mathrm{eV}$ ) has been observed after OHA treatment, which may be consistent with the result, presented in Table 5, that the peak corresponding to the " $\mathrm{O}, \mathrm{O}$ " five-ring chelate, in which $\mathrm{Fe}(\mathrm{III})$ chelates with OHA [24,30,31], as well as the peak area of O1s, were reduced by $20.93 \%$, from $128,494.2$ (a.u.), in the absence of OHA, to 101,602.7 (a.u.), in the presence of OHA. Thus, the OHA collector may compete with the hydroxyl groups of hydrophilic substances on the mineral surface to produce hydrophobic products and reduce the hydrophilic substances on the mineral surface (the mechanism is shown in Figure 9 [32,33]). Moreover, the Fe-OHA complexes are adsorbed onto the pyrrhotite $(\mathrm{ET}=24 \mathrm{~h})$ surface via a monodentate covalent bond between $\mathrm{Fe}^{3+}$ in the Fe-OHA complex, one $\mathrm{O}$ atom of the surface and two hydrogen bonds [32]. Meanwhile, a new peak (398.88 eV) was observed after OHA treatment, as shown in Figure 8, which may correspond to an "O, N" four-ring chelate [30]. 


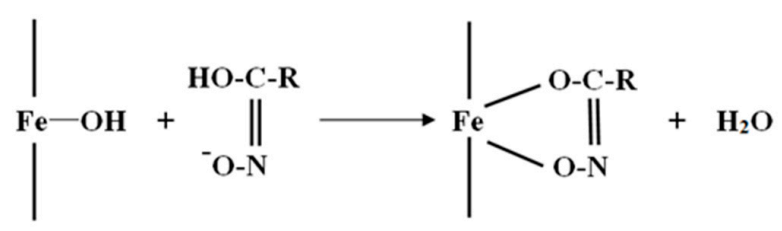

Figure 9. The reaction mechanism of OHA with iron (III) hydroxide on the oxidized pyrrhotite surface.

\section{Conclusions}

This paper indicates that copper-nickel sulfide ore can easily be oxidized, and the reaction mechanism of OHA on the surface-oxidized pyrrhotite was revealed through micro-flotation, adsorption tests, zeta potential measurements, and X-ray photoelectron spectroscopy (XPS) analyses. The following conclusions can be drawn:

1. This is a feasible way to find a suitable collector that can directly react with oxidation products on the surface of pyrrhotite. OHA can efficiently reclaim oxidized pyrrhotite and achieve the selective separation of pyrrhotite-serpentine artificially mixed minerals in a weak alkaline environment.

2. Adsorption tests, zeta potential measurements, and XPS analyses show that the selective adsorption of OHA on the surface of oxidized pyrrhotite $(\mathrm{ET}=24 \mathrm{~h})$ and serpentine is obvious.

3. The XPS analyses indicate that the OHA collector can chelate with $\mathrm{Fe}(\mathrm{OH})_{3}$ on the surface of oxidized pyrrhotite and form an "O, $\mathrm{O}$ " five-membered ring, and at the same time, the OHA collector may compete with the hydroxyl groups of hydrophilic substances on the mineral surface to produce hydrophobic products and reduce the hydrophilic substances on the mineral surface.

Author Contributions: Y.L., J.Z. and G.M. conceived and designed the experiments; J.Z. and G.M. performed the experiments and analyzed the data; Y.L. and G.M. contributed the reagents and materials; and J.Z. and G.M. wrote and revised the paper.

Funding: This research is supported by the National Basic Research Program of China (973 Program) (2014CB643402).

Conflicts of Interest: The authors declare no conflict of interest.

\section{References}

1. Yin, W.; Xue, J.; Li, D.; Sun, Q.; Yao, J.; Huang, S. Flotation of heavily oxidized pyrite in the presence of fine digenite particles. Miner. Eng. 2018, 115, 142-149. [CrossRef]

2. Newell, A.J.H.; Bradshaw, D.J.; Harris, P.J. The effect of heavy oxidation upon flotation and potential remedies for Merensky type sulfides. Miner. Eng. 2006, 19, 675-686. [CrossRef]

3. Xian, Y.; Wang, Y.; Wen, S.; Nie, Q.; Deng, J. Floatability and oxidation of pyrite with different spatial symmetry. Miner. Eng. 2015, 72, 94-100. [CrossRef]

4. Ejtemaei, M.; Nguyen, A.V. Characterisation of sphalerite and pyrite surfaces activated by copper sulphate. Miner. Eng. 2017, 100, 223-232. [CrossRef]

5. Nanthakumar, B.; Kelebek, S.; Katsabanis, P.D. Impact of oxidation on flotation of Ni-Cu sulphide ore with respect to grinding. Miner. Process. Extr. Metall. 2013, 116, 197-206. [CrossRef]

6. Tayebi-Khorami, M.; Manlapig, E.; Forbes, E.; Edraki, M.; Bradshaw, D. Effect of surface oxidation on the flotation response of enargite in a complex ore system. Miner. Eng. 2018, 119, 149-155. [CrossRef]

7. Peng, Y.; Zhao, S. The effect of surface oxidation of copper sulfide minerals on clay slime coating in flotation. Miner. Eng. 2011, 24, 1687-1693. [CrossRef]

8. Jacques, S.; Greet, C.J.; Bastin, D. Oxidative weathering of a copper sulphide ore and its influence on pulp chemistry and flotation. Miner. Eng. 2016, 99, 52-59. [CrossRef]

9. Fullston, D.; Fornasiero, D.; Ralston, J. Zeta potential study of the oxidation of copper sulfide minerals. Colloids Surf. A Phys. Eng. Asp. 1999, 146, 113-121. [CrossRef]

10. Raichur, A.M.; Wang, X.H.; Parekh, B.K. Quantifying pyrite surface oxidation kinetics by contact angle measurements. Colloids Surf. A Phys. Eng. Asp. 2000, 167, 245-251. [CrossRef]

11. Murphy, R.; Strongin, D.R. Surface reactivity of pyrite and related sulfides. Surf. Sci. Rep. 2009, 64, 1-45. [CrossRef] 
12. Mavros, P.; Matis, K.A. Innovations in Flotation Technology; Springer: Heidelberg, Germany, 1992; Volume 208, p. 538.

13. Legrand, D.L.; Bancroft, G.M.; Nesbitt, H.W. Surface characterization of pentlandite, $(\mathrm{Fe}, \mathrm{Ni})_{9} \mathrm{~S}_{8}$, by $\mathrm{X}-\mathrm{ray}$ photoelectron spectroscopy. Int. J Miner. Process. 1997, 51, 217-228. [CrossRef]

14. Feng, B.; Peng, J.; Zhang, W.; Luo, G.; Wang, H. Removal behavior of slime from pentlandite surfaces and its effect on flotation. Miner. Eng. 2018, 125, 150-154. [CrossRef]

15. Multani, R.S.; Williams, H.; Johnson, B.; Li, R.; Waters, K.E. The effect of superstructure on the zeta potential, xanthate adsorption, and flotation response of pyrrhotite. Colloids Surf. A Phys. Eng. Asp. 2018, 551, 108-116. [CrossRef]

16. Miller, J.D.; Li, J.; Davidtz, J.C.; Vos, F. A review of pyrrhotite flotation chemistry in the processing of PGM ores. Miner. Eng. 2005, 18, 855-865. [CrossRef]

17. Khan, A.; Kelebek, S. Electrochemical Aspects of Pyrrhotite and Pentlandite in Relation to their Flotation with Xanthate. Part-I: Cyclic Voltammetry and Rest Potential Measurements. J. Appl. Electrochem. 2004, 34, 849-856. [CrossRef]

18. Bunkholt, I.; Kleiv, R.A. Flotation of pyrrhotite and pyrite in saturated $\mathrm{CaCO}_{3}$ solution using a quaternary amine collector. Miner. Eng. 2015, 70, 55-63. [CrossRef]

19. Bunkholt, I.; Kleiv, R.A. Pyrrhotite oxidation and its influence on alkaline amine flotation. Miner. Eng. 2015, 71, 65-72. [CrossRef]

20. Zhang, C.; Liu, C.; Feng, Q.; Chen, Y. Utilization of N-carboxymethyl chitosan as selective depressants for serpentine on the flotation of pyrite. Int. J. Miner. Process. 2017, 163, 45-47. [CrossRef]

21. Bremmell, K.E.; Fornasiero, D.; Ralston, J. Pentlandite-lizardite interactions and implications for their separation by flotation. Colloids Surf. A Phys. Eng. Asp. 2005, 252, 207-212. [CrossRef]

22. Buswell, A.M.; Nicol, M.J. Some aspects of the electrochemistry of the flotation of pyrrhotite. J. Appl. Electrochem. 2002, 32, 1321-1329. [CrossRef]

23. Buckley, A.N.; Woods, R. Surface composition of pentlandite under flotation-related conditions. Surf. Interface Anal. 1991, 17, 675-680. [CrossRef]

24. Xu, H.; Zhong, H.; Tang, Q.; Wang, S.; Zhao, G.; Liu, G. A novel collector 2-ethyl-2-hexenoic hydroxamic acid: Flotation performance and adsorption mechanism to ilmenite. Appl. Surf. Sci. 2015, 353, 882-889. [CrossRef]

25. Natarajan, R.; Sharma, J.; Nirdosh, I. Adsorption of N-hydrocinnamoyl-N-phenylhydroxylamine on pure minerals. Adsorption 2010, 16, 541-548. [CrossRef]

26. Chen, G.; Grano, S.; Sobieraj, S.; Ralston, J. The effect of high intensity conditioning on the flotation of a nickel ore, part 2: Mechanisms. Miner. Eng. 1999, 12, 1359-1373. [CrossRef]

27. Wu, X.Q.; Zhu, J.G. Selective flotation of cassiterite with benzohydroxamic acid. Miner. Eng. 2006, 19, 1410-1417. [CrossRef]

28. Rashchi, F.; Finch, J.A. Polyphosphates: A review, their chemistry and application with particular reference to mineral processing. Miner. Eng. 2000, 10-11, 1019-1035. [CrossRef]

29. Chen, Y.; Feng, Q.; Zhang, G.; Liu, D.; Liu, R. Effect of Sodium Pyrophosphate on the Reverse Flotation of Dolomite from Apatite. Minerals 2018, 8, 278. [CrossRef]

30. Wang, P.; Qin, W.; Ren, L.; Wei, Q.; Liu, R.; Yang, C.; Zhong, S. Solution chemistry and utilization of alkyl hydroxamic acid in flotation of fine cassiterite. Trans. Nonferr. Met. Soc. China 2013, 23, 1789-1796. [CrossRef]

31. Sreenivas, T.; Padmanabhan, N.P.H. Surface chemistry and flotation of cassiterite with alkyl hydroxamates. Colloids Surf. A Phys. Eng. Asp. 2002, 205, 47-59. [CrossRef]

32. Tian, M.; Zhang, C.; Han, H.; Liu, R.; Gao, Z.; Chen, P.; Wang, L.; Li, Y.; Ji, B.; Hu, Y.; et al. Effects of the preassembly of benzohydroxamic acid with Fe (III) ions on its adsorption on cassiterite surface. Miner. Eng. 2018, 127, 32-41. [CrossRef]

33. Griffith, D.M.; Szőcs, B.; Keogh, T.; Suponitsky, K.Y.; Farkas, E.; Buglyó, P.; Marmion, C.J. Suberoylanilide hydroxamic acid, a potent histone deacetylase inhibitor; its X-ray crystal structure and solid state and solution studies of its $\mathrm{Zn}(\mathrm{II}), \mathrm{Ni}(\mathrm{II}), \mathrm{Cu}(\mathrm{II})$ and Fe(III) complexes. J. Inorg. Biochem. 2011, 105, 763-769. [CrossRef] [PubMed]

(C) 2018 by the authors. Licensee MDPI, Basel, Switzerland. This article is an open access article distributed under the terms and conditions of the Creative Commons Attribution (CC BY) license (http://creativecommons.org/licenses/by/4.0/). 